\title{
Bioactive Compound (Phenolic, Anthocianin, and Antioxidant) in Black Rice (Oryza sativa var. Pare Ambo) South Sulawesi
}

\author{
N Kiay ${ }^{1,2}$, A B Tawali ${ }^{3}$, M M Tahir ${ }^{3}$, M Bilang ${ }^{3}$
}

${ }^{1}$ Post-Graduate Student, Hasanuddin University, Makassar, South Sulawesi, Indonesia

${ }^{2}$ Faculty of Agricultural, Gorontalo University, Gorontalo, Indonesia

${ }^{3}$ Department of Food Science and Technology, Hasanuddin University, Jl. PerintisKemerdekaan Km.10, Makassar, Indonesia

\section{ABSTRACT}

Cereals are widely found in Indonesia and used as foodstuffs. Nutrient content of cereals vary from quantity and quality. Rice, one kind of cereals is commonly consumed by Indonesian community. There are some various types of rice such as brown rice, black rice and red rice. One type of rice, namely black rice is widely known as antioxidant source, for example black rice. This research be focused on the analysis of bioactive compound in black rice (Oryza sativa var Pare Ambo). This research using laboratory experiment methods to analyze total phenolic content, anthocianin, and antioksidan (free radical scavenging activity DPPH) black rice using spectrophotometer UV-vis. This research using complete random design (rancangan acak lengkap, RAL), thus obtained data were analyzed using statistic. Significant difference between groups were analyzed using ANOVA with $p<0,05$. The results showed that brown rice extract possess to total phenolic content (TPC) 3,97 $\mathrm{mg} / \mathrm{kg}$ gallic acid, free radical scavenging activity 52,30\%, anthocianin content 118,33 mg/kg (p>0,05). Black rice possess to total phenolic content $10,26 \mathrm{mg} / \mathrm{kg}$ gallic acid, free radical scavenging activity $62,67 \%$, anthocianin content $122,3 \mathrm{mg} / \mathrm{kg}$, red rice possess to total phenolic content(TPC) $7,48 \mathrm{mg} / \mathrm{kg}$ gallic acid, free radical scavenging activity $54,78 \%$, and anthocianin content $120 \mathrm{mg} / \mathrm{kg}$. Antioxidant activity from black rice caused by it phenolics compound that act as antioxidant. Spectra XRD Analysis for Determination of Vitamin B (Percentage of Vitamins) (B3, B5, B6) niacin, pantothenic acid and Riboflavin results showed the highest percentage of vitamin B5 (40,45). The results of the research were $88,21 \%$ carbohydrates, $8.36 \%$ protein, $1.74 \%$ fat, $11.17 \%$ water, $1.15 \%$ ash which amounts to $0.395 \mathrm{mg}$ calcium (Ca), $1.98 \mathrm{mg} / \mathrm{ml}$ Magnesium $(\mathrm{Mg})$ and $0.387 \mathrm{mg} / \mathrm{ml}$ iron $(\mathrm{Fe})$. In conclusion from this study, black rice has antioxidant activity and nutrient content, these products are expected to be native functional foods.

Keywords: Phenolic Content,Anthosianin, free radical scavenging activity, Vitamins, Black Rice, XRD

\section{INTRODUCTION}

Rice (Oryza sativa) is one of the most important cereal crops for human consumption in the world. The quality of rice affects consumers' acceptance and market value. The quality traits encompass physical appearance, cooking and eating properties and, more recently, nutritional value (Fitzgerald et al., 2009). The importance of nutritional quality can be viewed in two ways. On the one hand, micronutrient deficiency has been recognized in developing countries where rice is the main food, and fortification of nutrients by processing or biofortification by transgenic engineering to address 
particular deficiencies has emerged (Bouis et al., 2003; Welch and Graham, 2004). On the other hand, the frequency of life style related diseases such as diabetes, hypertension and obesity has increased over the last few decades in developed countries (Takaiwa et al., 2008). Many epidemiological studies have provided evidence that reduced risk of these diseases and some cancers is associated with the intake of whole grain including rice (Seal, 2006; Vitaglione et al., 2008). Whole grains have become popular in western countries, but more gradually accepted in developing countries with the improvement of living standards.

Black rice is a type of rice which contains more nutrients and active compound due to its color. Black rice contains anthocyanin pigments, such as cyanidin and peonidin in the bran layer. Anthocyanins are widely present in fruits, vegetables and red wine. Anthocyanins have been recognized as healthenhancing functional food ingredients due to their antioxidative activity (Jang and $\mathrm{Xu}$ et al., 2009; Kamiyama et al., 2009), anticancer activity (Spormann et al., 2008; Longo et al., 2008) and prevention of arterial sclerosis (Miyazaki et al., 2008). It has been also reported the characteristics of alcoholic beverages drunk through tubes in Thailand, Uganda, and Bahrain (Teramoto,2007).

Black rice is colored rice which is considered a health food (Park et al., 2008) which has been shown to have bioactive properties (Kong and Lee, 2010). Black rice contains anthocyanin which is a natural dye that is included in flavonoids and is used as an antioxidant Antioxidants are compounds or molecules that can prevent the oxidation process caused by free radicals (Chen et al, 2006). Based on previous research, an analysis of bioactive components in the form of total phenolic content (TPC), free radical scavenging activity (DPPH), anthocyanin and vitamins (niacin,
Pantothenic Acid and Riboflavin) with XRD (Percentage of Vitamins), with other additional data namely physical and chemical content (Contents water, protein, carbohydrate, fat and ash content, and mineral components in the test sample.

\section{MATERIALS AND METHODS}

\section{A. Materials}

Raw material used in this research are black rice (Oryza sativa var Pare Ambo), red rice, and brown rice. Rice samples will be bought from the farmer in Makassar and black rice in Tana Toraja Sout Sulawesi. Other materials are chemicals for laboratory analysis and will be bought in chemicals distributor in Makassar. The materials used in product analysis are quads, $\mathrm{K} 2 \mathrm{~S} 04, \mathrm{HgO}, \mathrm{H} 2 \mathrm{SO} 4$, H3BO4, NaOH- Na2S2O3 solution, HCL 0.02 N, HCl $0.1 \mathrm{~N}, \mathrm{NaOH} 0.1 \mathrm{~N}$, paper filter, red and blue metal indicator, and hexane.

\section{Tools}

The tools required in the making of black rice are the basin, stirrer spoon, gas stove, make a pan, large size stove, dryers and plastic packaging, silica gel, 100 and 80 mesh sieves, bowls, plates, small spoons and $1000 \mathrm{ml}$ measuring cups. The tools used in the analysis are pipette, volumetric pipette, desiccator, distillation equipment, Kjeldahl flask, Erlenmeyer, analytical balance, magnetic stirrer and hot plate cup, aluminum saucer, porcelain cup, petri dish, measuring cup.

The voltages input is $40 \mathrm{kV}$ and currents input is $30 \mathrm{~mA}$. Observation angle from are 200 to 800 , appliance type of $\mathrm{x}$-ray diffraction is Shidmadju $\mathrm{X}$ RD 7000. MAUD applications using standards data. After adjustment of diffraction pattern with standard data has been completed in MAUD application, then 
determine distance betwen atoms using Gaus View5.0 applications.

\section{B. Sample Preparation}

\section{Extraction procedure to determine the antioxidant properties \\ Each rice flour $(1.5 \mathrm{~g})$ was weighed} accurately and extracted at room temperature with $85 \%$ aqueous methanol under agitation using a magnetic stirrer for $30 \mathrm{~min}$. The mixtures were centrifuged at $2500 \mathrm{~g}$ for $10 \mathrm{~min}$ and the supernatants were collected. The residues were re- extracted twice under the same conditions, resulting finally in $50 \mathrm{ml}$ crude extract. All extracts were used as they were after centrifugation to determine TPC and antioxidant capacity.

\section{DeterminationofDPPHradicalscavenging ability}

Theantioxidant activity wasdetermined according toBrand- Williams, Cuvelier, and Berset (1995), with slight modifications.

KineticassaysofDPPHwithdifferentconcentrationsofth e extracts were carried outtodetermine the reaction time. A total of $1.5 \mathrm{~mL}$ of an ethanolic solution of DPPH (2.2316104 molL1), $200 \mathrm{lL}$ of sample, and 1.8 $\mathrm{mL}$ of ethanol were added to a test tube toafinal volume of3.5 mL.Thetubes were sealed, shaken and incubated for60 min in the dark at room temperature $(25 \pm 1 \mathrm{C})$. Theabsorbance wasrecorded at $\mathrm{k}=$ 517nmandtheability of extracts toscavenge the DPPHwascalculated using Eq. (3).

The percentage of radical-scavengingability was calculated by using the formula:

Scavengingability(\%)

$=[$ Absorbance $517 \mathrm{~nm}$ of control_Absorbance 517 $\mathrm{nm}$ of sample/Absorbance517 nm of control] x 100

\section{Analyses of anthocyanins and total phenolics} Anthocyanins from the black rice were quanti- fied by UV-Vis spectrophotometry (Shimadzu UV-1800), at $\mathrm{k}=374 \mathrm{~nm}$ and $\mathrm{k}=535 \mathrm{~nm}$, respectively.
The content of flavonoids and anthocyanins were determined using Eqs. (1) and (2), respec- tively (Lees \& Francis, 1972).

Total phenolic content was determined using the Folin-Ciocalteu method (Huber \& Rupasinghe, 2009; Singleton, Orthofer, \& Lamuela-Raventos, 1999), with slight modifications. To a $5.0 \mathrm{~mL}$ flask, $3.0 \mathrm{~mL}$ of ultrapure water, $250 \quad \mathbf{L}$ of Folin-Ciocalteu reagent $0.2 \mathrm{~N}$ and $250 \mathrm{IL}$ of properly diluted sample were added. The solution Total phenolic content was determined using the Folin Ciocalteu method (Huber \& Rupasinghe,2009; Singleton, Orthofer, \& Lamuela-Raventos, 1999), with slight modifications. Toa5. $0 \mathrm{~mL}$ flask, $3.0 \mathrm{~mL}$ of ultra purewater, 2501L of Folin-Ciocalteu reagent $0.2 \mathrm{~N}$ and $2501 \mathrm{~L}$ of properly diluted sample were added. The solution wasstirred for $5 \mathrm{~min}$ and $2501 \mathrm{~L}$ of a $10 \% \mathrm{Na}_{2} \mathrm{CO} 3$ solution $(\mathrm{w} / \mathrm{v})$ were added, and the volume was completed with ultra pure water. The mixture was incubatedat25Cina waterbath (99-20MQBTC) for $60 \mathrm{~min}$. The absorbance wasre cordedat761nm using as pectrophotometer (Shimadzu1800, Japan). The content of phenolic compounds was determined from the standard curve of gallicacid $\left(10-701 \mathrm{molL}^{1}\right.$, $\left.\mathrm{y}=0.01816 \mathrm{x} 0.01015 ; \mathrm{R}^{2}=0.9982\right)$. The results were expressedin $\mathrm{mg}$ of gallic acid equivalents per $100 \mathrm{~g}$ dry weight sample(mgGAE100g $\left.{ }^{1} \mathrm{DW}\right)$.

\section{Proximate Composition Analysis (AOAC, 2005)}

The proximate composition was determined according to AOAC (2005) methods. Crude protein content analyzed using the Kjeldahl method; crude lipid content referred to the Soxhlet method; while ash content through ash samples over-night at $550^{\circ} \mathrm{C}$. Moisture content was by drying samples overnight at 
$105^{\circ} \mathrm{C}$ until constant weight was achieved,as well as carbohydrate content was calculated by differences.

\section{Water content of oven method (AOAC 1996)}

Determination of water content based on the difference in weight for example before and after dried. At first the empty cup is dried in the oven for 30 minutes at $105^{\circ} \mathrm{C}$. then cooled in the eksikator for 15 minutes, Then weighed. 3-5 gram of sample inserted into the cup then dried in $105^{\circ} \mathrm{C}$ oven for 6 hours. Cup cooled in eksikator for 30 minutes, then weighed. The water content determined by the formula

$$
\text { Water Content }(\%)=\frac{B-C}{B-A} \times 100 \%
$$

\section{Protein Content (Sudarmadji, 1984)}

Take $10 \mathrm{ml}$ of protein solution and diluted to $100 \mathrm{ml}$ with the distilled water in the flask, the solution is then put into a $500 \mathrm{ml}$ Kjeldahl flask and $10 \mathrm{ml}$ of $\mathrm{H}_{2} \mathrm{SO}_{4}(93 \%-98 \%$ free $\mathrm{N})$ add5 grams of a mixture of $\mathrm{H}_{2} \mathrm{BO}_{3}, \mathrm{Na}_{2} \mathrm{SO}_{4}-\mathrm{HgO}$ for catalyst.Boil until clear and continued for another 30 minutes. After a cold washed in a Kjeldahl flask with distilled water then boiled again for 30 minutes.

Once cool add $140 \mathrm{ml}$ of distilled water, and added 35 $\mathrm{ml} \mathrm{NaOH}-\mathrm{Na} 2 \mathrm{~S} 2 \mathrm{O} 3$ and a few grains of zinc. Then it was distilled, $100 \mathrm{ml}$ of distillate accommodated in an erlenmeyer containing $25 \mathrm{ml}$ of boric acid saturated solution and a few drops of PP indicator. Solution obtained with $0.02 \mathrm{~N} \mathrm{HCl}$.

\section{Ash content of gravimetric method (AOAC 1996)}

3-5 grams of sample weighed and put into the cup, then burned in the Bunsen until no smoke. After it inserted in a furnace, burned to gray ash. Ash carried out in two stages, first at a temperature of $400^{\circ} \mathrm{C}$ and then a temperature of $550^{\circ} \mathrm{C}$. After the weight of the cup is constant, the cup then cooled in a desiccator and weighed. Ash content determined by the formula:

$$
\text { Ash Content }(\%)=\frac{A}{B} x 100 \%
$$

Fat Content (Ivıetoae soxnıet), suaarmaaj1,1997.

The mash sample was weighed as much as $10 \mathrm{~g}$ and added to the thimble. Then the thimble is inserted into the Soxhlet extraction tube. The sample was extracted using sufficient petrolli ether solvent for + 4-6 hours. Petrolium ether containing fat extract is a weighing bottle that is clean and has heavy weight and is evaporated over the rice bath until it is not thick. Oven dry at a temperature of $1000 \mathrm{C}$ to constant weight. The residual weight in the bottle is weighed and declared heavy.

\section{carbohydrate content (By Difference)}

carbohydrate $(\%)=100 \%$ - (water content + ash content + fat content + protein content)

\section{Statistical analysis}

Data analysis using variance analysis (ANOVA). The results of the data that showed a significant effect ( $\alpha$ $=0.05$ ), the real difference test was performed using Duncan's multiple distance difference test.

\section{RESULTS AND DISCUSSION}

\section{A. Bioactive Compound}

The results showed thatblack rice extract possess to total phenolic content $3,84 \mathrm{mg} / \mathrm{kg}$ gallic acid, free radical scavenging activity 52,30-62,67\%, anthocianin 118,33-123,33 ppm ( $>0,05)$. Brown rice possess to total phenolic content $3,97 \mathrm{mg} / \mathrm{kg}$ gallic acid, free radical scavenging activity $52,30 \%$, and Anthocianin 118,33mg/100 g sample, Black rice possess to total phenolic content $10,26 \mathrm{mg} / \mathrm{kg}$ gallic acid. The phenolic content varied statistically $(\mathrm{P}<$ 0.001) 123.33 mg100g.linear regressionanalysis showed that the model wassignificant $(\mathrm{P}<0.001)$ 
Table 1.Total Phenolic Content (TPC), Anthosianin and Free radicalscavenging activity (DPPH)

\begin{tabular}{cccc}
\hline Sampel & $\begin{array}{c}\text { Phenolic } \\
(\mathrm{mg} / \mathrm{Kg}) \\
\mathrm{GA}\end{array}$ & $\begin{array}{c}\text { Anthocianin } \\
(\mathrm{mg} / \mathrm{kg})^{*}\end{array}$ & $\begin{array}{c}\text { Free radical } \\
\text { scavenging } \\
\text { activity }(\%)^{*}\end{array}$ \\
\hline \multirow{2}{*}{ BR1 } & $3,97 \pm 0.02$ & $\begin{array}{c}118,33 \pm \\
0.58\end{array}$ & $52,30 \pm 0.69$ \\
& \multicolumn{3}{c}{$120,33 \pm$} \\
RR2 & $7,48 \pm 0.07$ & 0.58 & $54,78 \pm 0.80$ \\
& & $123,33 \pm$ \\
BR3 & $10,26 \pm 0.03$ & 1.53 & $62,67 \pm 0.58$ \\
& &
\end{tabular}

Description :Valueswith different letters in the same column show significantly different $(\mathrm{p}<0.05)$

Brown Rice (BR1) ; Red Rice (RR2) ; Black Rice (BR3)

The results of research on antioxidant activity of black rice extract. The antioxidant activity of the average black rice extract extracted with ethanol had the highest antioxidant activity of $62.67 \%$, the total phenol obtained had a positive relationship with antioxidant activity. This has been supported by Walter and Marchesan (2011) that the higher the total phenol, the higher antioxidant activity. Muntana and Prasong (2010) also reported higher antioxidant activity of black rice than brown rice and brown rice. According to Itani et al. (2002); Goffman and Bergman (2004); Zhang et al. (2006) in Walter and Marchesan (2011) state that the total phenol concentration in rice seeds has a positive contribution to antioxidant activity and is important in antioxidant activity in rice grains. Apart from a large amount of antioxidants, concentrated in larger quantities, the more the composition, the more antioxidant content increases. A similar thing was published by Poumorad et al. (2006) that extracts with the highest content of phenolic compounds showed the highest antioxidant activity. This antioxidant activity is involved by hydroxyl groups in phenolic compounds which act as free radical catchers. Determination of a solution of black rice free radical capture can be used by testing 1,1diphenyl-2-pikrillhidrazil (DPPH) radicals. The color reduction level of the resolution adds radical antidote efficiency. Testing the DPPH free radical prevention activity using a spectrophotometer was carried out by only looking at the extract with the DPPH solution. Sorbance is needed at $\lambda 517 \mathrm{~nm}$.

The anthocyanins derive from the flavylium cation, and contain oneor morehydroxyl substituents Similarly, Kimetal. (2014) studied the chemical composition and antioxidant activity (ABTS, FRAP, and $\mathrm{DPPH})$ nine varieties of pigmented rice (O. sativa L.) and verified that cyanidin-3-glucoside, peonidin3-glucoside, pro anthocyanidin dimers, proanthocyanidin trimers, and catechin presented a high and significant correlation with the antioxidant data. Inarecent study conducted by Jun, Shin, Song, andKim (2015).

Antioxidant activity from black rice caused by it phenolics compound that act as antioxidant. As conclusions of this research, black rice possess an antioxidant activity. Then black rice extract possess high antioxidant activity. including otherfunctionalgroups (sugars, forexample). Thepresence ofhydroxyl groups provides antioxidant properties forthe donation ofhydrogenatomsfor reactive species, with the formation of stable products. Therefore, the higher the anthocyanin content, the higher the antioxidant activity(Zhang, Shao,Bao,\& Beta,2015). Important for the body due to the maintenance of healthy skin, proper functioning of the nervous system and secretion of bile and stomach normal. 
(Winarno, 1989). The analysis results, water content of black rice ranges from 11,00-11,14\%.

\section{B. XRD (Percentage of Vitamin)}

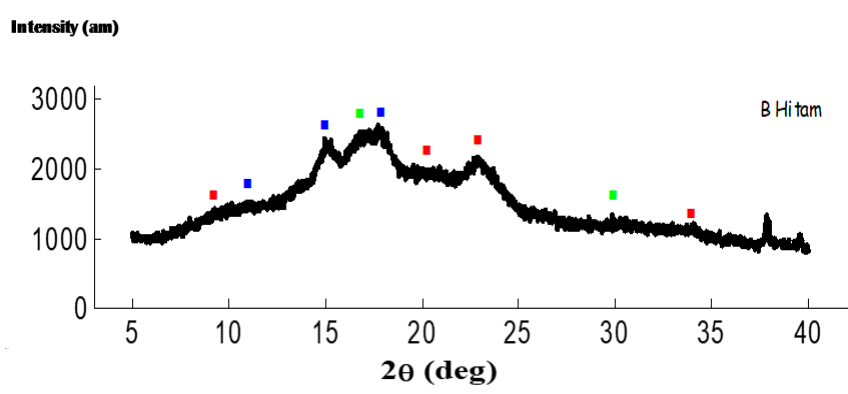

Figure 1. XRD data in study (diffraction peak assignment)

Figure 1 show, the percentage of vitamin B3 (Niacin) in black rice (6.42) shows that black rice has the main function as a nutrient that is very

Percentage of vitamin (B5) pantothenic acid in black rice (40.45). Vitamins are organic nutrients that function specifically and importantly in the human body's system and are very important for maintaining optimal health. Water-soluble vitamins include the B-complex group Niacin, also known as nicotinic acid, and niacinamide (nicotinamide) is a form of vitamin B3. In the release of energy and transfer of fat, protein and, proper circulation, maintenance of healthy skin, proper functioning of the nervous system and secretion of bile and gastric fluid. Vitamin B3 deficiency causes a condition called pellagra (Chand and Savitri, 2016).

\section{Proximate Composition}

Table 2 shows the proximate composition of Black rice. There was no significant difference $(\mathrm{P}>0.05)$ in protein, lipid, moisture content and ash content of black rice. Water is an important component in foods that can affect the appearance, texture, and flavor of food. The water content in foodstuffs in determine acceptability, freshness and durability of food
Table 2. Proximate Composition Black Rice

\begin{tabular}{lc}
\hline \multicolumn{1}{c}{ Sampel } & Black Rice(\%)* \\
\hline Watercontent & $11,17 \pm 0.76^{\mathrm{b}}$ \\
Protein & $8,36 \pm 0.35^{\mathrm{b}}$ \\
Carobhydrate & $88,21 \pm 0.39^{\mathrm{b}}$ \\
Fat & $1,74 \pm 0.27^{\mathrm{b}}$ \\
Ash Content & $1,15 \pm 0.06^{\mathrm{a}}$ \\
\hline
\end{tabular}

Description :Valueswith different letters in the same column show significantly different $(\mathrm{p}<0.05)$

Brown Rice (BR1) ; Red Rice (RR2) ; Black Rice (BR3)

Protein is an essential nutrient for the body, since this substance is either serves as fuel and as builder substance and regulator. Protein is a source of amino acids that contain elements $\mathrm{C}, \mathrm{H}, \mathrm{O}$, and $\mathrm{N}$, which are not by fat or carbohydrates (Winarno, 1989). Analysis result shown black rice protein content ranged from 8,01-9(\%) and fat content ranged from 1,5-1,9\%.

The carbohydrate main source of black rice carbohydrate content. Determination of carbohydrates contents calculated by difference, by calculating the difference between $100 \%$ total moisture, ash, protein, and fat. Analysis result shown black rice carbohydrate content ranged from $88,00-88,6 \%$.

Most of foodstuff, approximately $96 \%$ consisting of organic materials and water, the rest is mineral elements. Mineral elements also known as an inorganic substance or ash. In the burning process, organic material burnt but not inorganic substances, therefore called ash (Winarno, 1989). Analysis result shown black rice ash content ranged from $1-1.45 \% \mathrm{bk}$. 
N Kiay et al.Int J Sci Res Sci Technol.March-April-2019; 6(2) : 143-150 


\section{Mineral}

Table 3.MineralComposition Black Rice

\begin{tabular}{ll} 
Variable & Result $(\mathrm{mg} / \mathrm{ml})$ \\
\hline Calcium $(\mathrm{Ca})$ & 0,395 \\
Magnesium $(\mathrm{Mg})$ & 1,98 \\
Iron $(\mathrm{Fe})$ & 0,387 \\
\hline
\end{tabular}

Table 3 showsMineral composition black rice of Calcium (Ca) 0.395 mg/ml, Magnesium (Mg) 1.98 $\mathrm{mg} / \mathrm{ml}$ and Iron $(\mathrm{Fe}) 0.387 \mathrm{mg} / \mathrm{ml}$, the highest mineral content is variable Magnesium $(\mathrm{Mg})$ with a value of $1,98 \mathrm{mg} / \mathrm{ml}$.

\section{CONCLUSION}

The results of this study show that there are significant diferences in phenolic content, antioxsidant (Free radicalscavenging activityDPPH) and anthosianin content.This antioxidant activity is involved by hydroxyl groups in phenolic compounds which act as free radical scavenging activity.In conclusion from this study, black rice has antioxidant activity and nutrient content, these products are expected to be native functional foods.

\section{ACKNOWLEDGMENTS}

This work is funded by Higher Education Directorate,Ministerial of Research and Technology Indonesia through Doctoral research grant program.

\section{REFERENCES}

[1]. AOAC (Association of Official Analytical Chemyst) (2005). Official Method of Analysis of The Association of Official Analytical of
Chemist. Arlington (USA): The Association of Official Analytical Chemist, Inc.

[2]. Bouis HE, Chassy BM, Ochanda JO. 2003. Genetically modified food crops and their contribution to human nutrition and food quality. Trend Food Sci Tech 14:191-209

[3]. Fitzgerald MA, McCouch SR, Hall RD. 2009. Not just a grain of rice: the quest for quality. Trend Plant Sci 14:133-139

[4]. Gani, A., Wani SM, Masoodi FA and Gousia Hameed. 2012. Whole-Grain Cereal Bioactive Compounds and Their Health Benefits: (A Review) J Food Process Technol 2012, 3:3

[5]. Hu C, Zawistowski J, Ling W, Kitts DD. 2003. Black rice (Oryza sativa L. indica) pigmented fraction suppresses both reactive oxygen species and nitric oxide in chemical and biological model systems. J Agric Food Chem 51: 52715277.

[6]. Jun, H. I., Shin, J. W., Song, G. S., \& Kim, Y. S. (2015). Isolation and identification of phenolic antioxidants in black rice bran. Journal of Food Science, 80(2), C262-C268.

[7]. Kim, G. R., Jung, E. S., Lee, S., Lim, S., Ha, S., \& Lee, C. H. (2014) Combined mass spectrometrybased metabolite profiling of different pigmented rice (Oryza sativa L.) seeds and correlation with antioxidant activities. Molecules, 19,15673-5686.

[8]. Krawinkel MB. 2007. What we know and don't know about Golden Rice. Nat Biotechnol 25:623.

[9]. Lees, D. H., \& Francis, F. J. (1972). Standardization of pigment analyses in cranberries. HortScience, 7, 83-84.

[10]. Lee, J. H. (2010). Identifications and quantification of anthocyanins from the grains of black rice (Oryza sativa L.) varieties. Food Science and Biotechnology, 19,391-397. 
[11]. Martínez-Tome M, Murcia MA, Frega N, Ruggieri S, Jiménez AM. 2004. Evaluation of antioxidant capacity of cereal brans. J Agric Food Chem 52: 4690-4699.

[12]. Park, Young Sam, Sun-Joong Kim, and Hyo- Ihl Chang. 2008. Isolation of Anthocyanin from Black Rice (Heugjinjubyeo) and Screening of its Antioxidant Activities Kor. J. Microbiol. Biotechnol. Vol. 36, No. 1, 55-60(2008)

[13]. Perez-Jiménez J, Saura-Calixto F. 2005. Literature data may underestimate the actual antioxidant capacity of cereals. J Agric Food Chem 53: 5036-5040.

[14]. Seal CJ (2006) Whole grains and CVD risk. Proc Nutr Soc 65:24-34Takaiwa F, Yang L, Yasuda H (2008) Health- promoting transgenic rice: application of rice seeds as a direct delivery system for bioactive peptides in human health. In: Hirano HY, Sano Y, Hirai A, Sasaki T (eds) Rice biology in the genomics era. Springer, Berlin pp 357-373

[15]. Teramoto, Y.1*, Koguchi, M.1, Wongwicharn, A.2 and Saigusa, N. 2011. Production and antioxidative activity of alcoholic beverages made from Thai ou yeast and black rice (Oryza sativa var. Indica cv. Shiun) African Journal of Biotechnology Vol. 10(52), pp. 10706-10711,

[16]. Vitaglione P, Napolitano A, Fogliano V (2008) Cereal dietary fibre: a natural functional ingredient to deliver phenolic compounds into the gut. Trend Food Sci Tech 19:451-463

[17]. Xu Z, Hua N, Godber JS. 2001. Antioxidant activity of tocopherols, tocotrienols, and gamma- oryzanol components from rice bran against cholesterol oxidation accelerated by 2 , 20-azo bis (2-methylpropionamidine) dihydrochloride. J Agric Food Chem 49: 20772081.

[18]. Yu L, Haley S, Perret J, Harris M, Wilson J. 2002. Free radical scavenging properties of wheat extracts. J Agric Food Chem 50: 16191624.

[19]. Yu L, Zhou k, Parry Jw. 2005. Inhibitory effects of wheat bran extracts on human LDL oxidation and free radicals. LWT 38: 463-470.

[20]. Zieli Å, Ki H, Koz A, Owska H. 2000. Antioxidant activity and total phenolics in selected cereal grains and their different morphological fractions. J Agric Food Chem 48: 2008-2016.

[21]. Winarno, F. G., F. Srikandidan D. Fardiaz. 1988. Food Technology Introduction. PT GramediaPustakaUtama. Jakarta

[22]. Winarno, F. G., F. Srikandidan D. Fardiaz.. 2002Food and Nutrient Chemistry. Jakarta. PT GramediaPustakaUtama

[23]. Zhang, H., Shao, S., Bao, J., \& Beta, T. (2015). Phenolic compounds and antioxidant properties of breeding lines between the white and black rice. Food Chemistry, 172, 60-639.

\section{Cite this article as :}

N Kiay, A B Tawali, M M Tahir, M Bilang, "Bioactive Compound (Phenolic, Anthocianin, and Antioxidant) in Black Rice (Oryza sativa var. Pare Ambo) South Sulawesi", International Journal of Scientific Research in Science and Technology (IJSRST), Online ISSN : 2395-602X, Print ISSN : 2395-6011, Volume 6 Issue 2, pp. 143-150, March-April 2019. Available at doi : $\quad$ https://doi.org/10.32628/IJSRST196222 Journal URL : http://ijsrst.com/IJSRST196222 